\title{
Radiological assessment of the Bayer process
}

\author{
A. Goronovski ${ }^{1}$, J. Vind ${ }^{2,3}$, V. Vassiliadou ${ }^{2}$, D. Panias ${ }^{3}$, A. H. Tkaczyk ${ }^{1}$ \\ ${ }^{1}$ Institute of Physics, University of Tartu, W. Ostwaldi 1, 50411 Tartu, Estonia \\ ${ }^{2}$ Aluminium of Greece plant, Metallurgy Business Unit, Mytilineos S.A., Agios Nikolaos, \\ Boeotia, Greece \\ ${ }^{3}$ School of Mining and Metallurgical Engineering, National Technical University of Athens, \\ Athens, Greece \\ Corresponding author: Andrei Goronovski \\ e-mail:goronovski@gmail.com
}

Address: W. Ostwaldi 1 D515, 50411 Tartu, Estonia

\begin{abstract}
Naturally occurring radionuclides were studied through the Bayer process by modelling their mass flows. Aluminium of Greece (AoG) provided sample materials and plant data from most process stages. Measurements of radionuclide concentrations were carried out by gammaray spectroscopy.

Measurements have shown that for the AoG specific plant, the majority of the natural radionuclides were introduced with karst bauxites, which showed higher activity concentrations for nuclides compared to lateritic bauxites. Most of these nuclides accumulated in the bauxite residue, while only a minor portion of uranium isotope ${ }^{238} \mathrm{U}$ was found in alumina, corresponding to $3 \%$ of its input value. Uranium was observed to partially dissolve in the process liquors similarly to ${ }^{40} \mathrm{~K}$, whereas the latter was not associated with aluminium hydroxide.

All the materials studied in the current research work had radionuclide concentrations well below the screening limits set by EURATOM Basic Safety Standard, indicating that these naturally occurring radionuclides do not pose a radiological hazard for workers of the AoG plant or the public.
\end{abstract}

\section{Keywords}

Bayer Process, Bauxite Residue, Aluminium Production, NORM, Uranium, Thorium

\section{Declaration of interest}

Declarations of interest: none. 


\section{Introduction}

The Bayer process is an industrial method of bauxite pressure digestion in strong sodium hydroxide caustic solutions. As a result, aluminium hydroxide is selectively extracted, crystallized from the process liquor and then calcined to metallurgical grade alumina (Chin, 1988). The current study is performed in association with Aluminium of Greece plant (AoG), which utilizes both karst (Bardossy, 1982) and lateritic (Bardossy and Aleva, 1990) bauxites. Karst bauxites account for roughly $80 \%$ of the plant bauxite feed, coming mainly from Parnassos-Ghiona region in Greece and a small portion coming from Turkey. The rest of the bauxite feed is lateritic (also known as tropical or gibbsitic) bauxite from Ghana or Brazil.

After extraction of aluminium hydroxide, insoluble fractions of bauxite ore are accumulated in the by-product- Bauxite Residue (BR), including natural radionuclides $\left({ }^{40} \mathrm{~K},{ }^{232} \mathrm{Th},{ }^{238} \mathrm{U}\right.$ and their decay products) that appear in feed bauxites (Cuccia et al., 2011; Miller and Miller, 2016). These radionuclides, often referred as primordial, have half-lives comparable to the lifetime of the universe and have been presented in the Earth crust since its formation. Even though these radionuclides are "natural", their exposure remains potentially hazardous and has to be taken into account (Joyce et al., 2017).

The radionuclide content in bauxites is partially due to the presence of radionuclide rich minerals such as ilmenite and monazite (IAEA, 2003) and can vary significantly worldwide: 10$9000 \mathrm{~Bq} / \mathrm{kg}{ }^{238} \mathrm{U}, 35-1400 \mathrm{~Bq} / \mathrm{kg}{ }^{232} \mathrm{Th}$ and $10-600 \mathrm{~Bq} / \mathrm{kg}{ }^{40} \mathrm{~K}$. In bauxites mined in Greece (mostly used at the currently investigated plant) thorium was previously reported to be associated with titanium mineral phases present particularly in anatase (Gamaletsos et al., 2011). In bauxite residue, thorium has been shown to be chemically associated with Bayer process derived (nano-)perovskite $\left(\mathrm{CaTiO}_{3}\right)$ (Gamaletsos et al., 2016) and rare earth ferrotitanate ( $(\mathrm{REE}, \mathrm{Ca}, \mathrm{Na})(\mathrm{Ti}, \mathrm{Fe}) \mathrm{O}_{3}$ ) compounds (Vind et al., 2018b). A part of uranium has been determined to be associated with chemically durable zircon $\left(\mathrm{ZrSiO}_{4}\right)$ mineral phase both in bauxite and in bauxite residue (Vind et al., 2018c).

In the current study, comprehensive radionuclide mass balance through the entire Bayer process was modeled to (1) establish relations between input and output radionuclide concentrations in the Bayer process so that it can be designed taking into account radiological considerations; (2) obtain comprehensive radionuclide mass balance knowledge within Bayer process; (3) aid prospective BR utilization flowsheets in predicting the behavior of radionuclides starting from bauxite until various final products.

\subsection{Process description in the Aluminium of Greece}

Aluminium of Greece has two main bauxite sources- karst and lateritic bauxites, see Figure 1. Greek karst bauxites mined from bauxite horizon 3 (B3) (Deady et al., 2016) (namely DelphiDistomon and S\&B bauxites, material explanations are provided in Table 1) go through decalcitation stage and are sent directly to the next processing stage or stockpiled for later usage. This is a beneficiation process to remove most of the undesirable limestone contamination of the ore due to its geology and is performed by exploiting heavy media 
separation (Lavalou et al., 1999). Other karst bauxites (Turkish and HS bauxites) go directly to grinding and preheating stage of the Bayer process.

Next, karst and lateritic bauxites are subjected to crushing and grinding stages, each one on a separate branch. Lateritic bauxite slurry is retained in a desilication unit so that large part of reactive silica is converted to de-silication product before entering the digestion and lime is added to karst bauxite mixture to improve grindability and digestion (Mucsi et al., 2011). Karst bauxite is digested under pressure (5.8-6.0 MPa) at $255^{\circ} \mathrm{C}$ with caustic liquor recycled in the process (Balomenos et al., 2009). Tropical bauxite slurry is introduced to karst bauxite slurry after digestion of karst bauxite in the flashing stage. This process is called "sweetening" and the intention is to improve liquor productivity by introducing trihydrate bauxite into digestion stream (Lavalou et al., 1999). Next, settling, washing, precipitation and calcination are performed conventionally (Hind et al., 1999), (Paspaliaris et al., 2001).

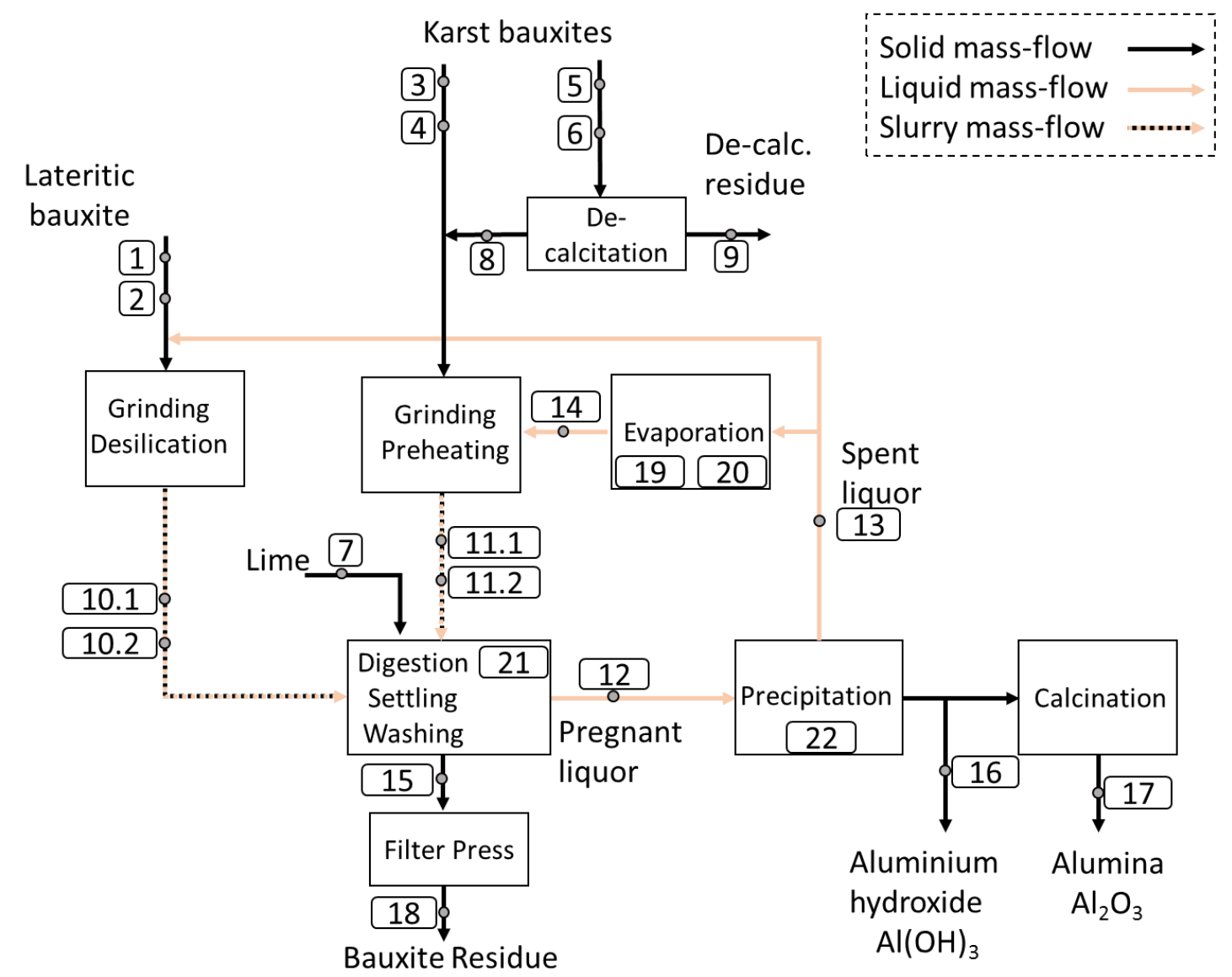

Figure 1. Bayer process diagram at the Aluminium of Greece.

Table 1. Description of the sampled materials.

\begin{tabular}{cc|c} 
Number & Material & Description \\
Input materials
\end{tabular}




\begin{tabular}{|c|c|c|}
\hline 2 & Ghana Bauxite & $\begin{array}{l}\text { Lateritic bauxite from Ghana, Awaso deposit. At the time of sampling, } \\
\text { this material was not processed. }\end{array}$ \\
\hline 3 & Turkish bauxite & Karst bauxite from Turkey, western Taurides range and Milas area. \\
\hline 4 & HS bauxite & Karst bauxite from Greece, Parnassos-Ghiona area, from horizon B2. \\
\hline 5 & S\&B bauxite & $\begin{array}{l}\text { Karst bauxite from Greece, Parnassos-Ghiona area, from horizon B3. } \\
\qquad \text { Extracted by S\&B Industrial Minerals S.A. }\end{array}$ \\
\hline 6 & $\begin{array}{l}\text { Delphi-Distomon } \\
\text { bauxite }\end{array}$ & $\begin{array}{l}\text { Karst bauxite from Greece, Parnassos-Ghiona area, from horizon B3. } \\
\text { Extracted by company Delphi-Distomon S.A. }\end{array}$ \\
\hline 7 & Lime & Lime, $\mathrm{CaO}$ from local quarry. \\
\hline & & Decalcitation unit \\
\hline 8 & $\begin{array}{l}\text { Decalcitated } \\
\text { bauxite }\end{array}$ & $\begin{array}{l}\text { Mixed S\&B / Delphi-Distomon bauxite, after limestone separation } \\
\qquad \text { (“decalcitatation”). }\end{array}$ \\
\hline 9 & $\begin{array}{l}\text { Decalcitation } \\
\text { residue }\end{array}$ & $\begin{array}{l}\text { Limestone residue that is separated from Parnassos-Ghiona B3 horizon } \\
\text { bauxite. Besides limestone, contains also a significant proportion of } \\
\text { rejected bauxite material. }\end{array}$ \\
\hline \multicolumn{3}{|r|}{ Intermediate materials and process liquors } \\
\hline 10.1 & $\begin{array}{l}\text { Solid phase } \\
\text { lateritic slurry }\end{array}$ & Solid fraction of lateritic bauxite slurry from pre-desilication unit. \\
\hline 10.2 & $\begin{array}{l}\text { Liquid phase } \\
\text { lateritic slurry }\end{array}$ & $\begin{array}{l}\text { Liquid fraction of lateritic bauxite slurry from pre-desilication unit. } \\
\text { Measurements are not available. }\end{array}$ \\
\hline 11.1 & $\begin{array}{l}\text { Solid phase karstic } \\
\text { slurry }\end{array}$ & $\begin{array}{l}\text { Solid fraction of karst bauxite slurry, from grinding and preheating } \\
\text { units of karst bauxite. }\end{array}$ \\
\hline 11.2 & $\begin{array}{l}\text { Liquid phase } \\
\text { karstic slurry }\end{array}$ & $\begin{array}{l}\text { Liquid fraction of karst bauxite slurry, from grinding and preheating } \\
\text { units of karst bauxite. Measurements are not available. }\end{array}$ \\
\hline 12 & Pregnant liquor & Pregnant liquor, from the outlet of settling and security filtration. \\
\hline 13 & Spent liquor & Spent liquor, from the outlet of precipitation. \\
\hline 14 & $\begin{array}{l}\text { Concentrated } \\
\text { liquor }\end{array}$ & $\begin{array}{l}\text { Concentrated spent liquor, from the output of evaporation unit, } \\
\text { routed to karst bauxite grinding. }\end{array}$ \\
\hline 15 & BR slurry & Bayer process residue prior to filter press \\
\hline \multicolumn{3}{|r|}{ Output materials } \\
\hline 16 & Hydrated alumina & Aluminium hydroxide, $\mathrm{Al}(\mathrm{OH})_{3}$ \\
\hline 17 & Calcined alumina & Alumina, $\mathrm{Al}_{2} \mathrm{O}_{3}$ \\
\hline 18 & Bauxite residue & Bauxite residue \\
\hline \multicolumn{3}{|r|}{ Scales } \\
\hline 19 & $\begin{array}{l}\text { White scales from } \\
\text { evaporation }\end{array}$ & \multirow{2}{*}{$\begin{array}{l}\text { Scales from evaporation, in contact with spent liquor sub-divided by } \\
\text { color - white (major fraction) and red (minor fraction). }\end{array}$} \\
\hline 20 & $\begin{array}{l}\text { Red scales from } \\
\text { evaporation }\end{array}$ & \\
\hline
\end{tabular}




\begin{tabular}{|c|c|c|}
\hline 21 & $\begin{array}{c}\text { Scales from } \\
\text { digester }\end{array}$ & Scales from autoclave \\
\hline 22 & $\begin{array}{l}\text { Scales from } \\
\text { precipitators }\end{array}$ & Scales from precipitators \\
\hline
\end{tabular}

\section{Methodology}

\subsection{Sampling}

Solid and liquid samples from process input, output and intermediate stages were collected during a 3-day period to represent a timely snapshot of all the materials interacting in the process, except sodium hydroxide. The volume of added sodium hydroxide was negligible during testing period $(<0.4 \%)$ compared to volume of recirculating liquor. In addition, various scale samples were collected to inspect whether they accumulate any radionuclides, as scales formed in the pipes or storage tanks are a possible radiological hotspot (e.g. in phosphate (Beddow et al., 2006) or oil industry (Bou-Rabee et al., 2009)). In the Bayer process specifically, accumulation of potassium in the heat exchangers where spent liquor is recycled has been reported to reach $0.23-1.23 \%$ (Armstrong, 1999) of potassium in scales, corresponding to $90-381 \mathrm{~Bq} / \mathrm{kg}$ of ${ }^{40} \mathrm{~K}$.

One-tone test batches of bauxites were collected by Aluminium of Greece, from which sampling of the feed material was performed. Site-specific sampling points have been used to gather Bayer liquors, aluminium hydroxide and lime specimens according to AoG internal protocols. Bauxite residue samples were collected before and after filter pressing.

During sampling period, the only lateritic bauxite used the plant was bauxite from Brazil. Several karst bauxites were used (see Table 1 for more details) from Parnassos-Ghiona deposit in Greece and from Milas area in Turkey. Parnassos-Ghiona deposits are subdivided into three bauxite horizons (B1-B3) that are intercalated between limestones in the deposit (Deady et al., 2016). The uppermost horizon, B3, is mainly exploited and the exploitation of middle horizon, B2, has recently ceased by AoG. The lower B1 horizon in not industrially relevant. The sampled Greek bauxites originate from different mines.

The samples have been kept intact for at least 6 months after sampling in order for ${ }^{234} \mathrm{Th}$ (which is measured) to reach secular equilibrium with ${ }^{238} \mathrm{U}$, which is studied. The half-life of ${ }^{234} \mathrm{Th}$ is 24.1 days and after 6 month potential difference between ${ }^{234} \mathrm{Th}$ and ${ }^{238} \mathrm{U}$ would be below $1 \%$. Samples have been dried at $105^{\circ} \mathrm{C}$ for a day to remove humidity and at least 3 weeks have passed between preparation and measurement time, so that secular equilibrium has been reached for other radionuclides.

\subsection{Measurements}

Gamma-ray spectroscopy method is applied to quantify radionuclide content in the full Bayer process chain. Following naturally occurring isotopes are measured: ${ }^{40} \mathrm{~K},{ }^{238} \mathrm{U},{ }^{226} \mathrm{Ra}$ (decay product of uranium), ${ }^{228} \mathrm{Ra}$ and ${ }^{228} \mathrm{Th}$ (decay products of ${ }^{232} \mathrm{Th}$ ). Two different long-lived 
isotopes from the decay chains of primordial uranium and thorium are selected as these isotopes have different chemical properties and therefore might behave differently during chemical processing. More details regarding selection of measured nuclides and gamma lines used in measurements are provided in Table 2.

Measurement system was calibrated with standards prepared from RGU-1 and RGTh-1 reference materials certified by IAEA (IAEA, 1987). Sample geometry, container and sealing were identical to standards. Efficiency transfer and coincidence summing analytical corrections were implemented with the help of computer code EFFTRAN (Vidmar, 2005), to account for potential effects of different sample matrixes and densities.

Table 2. Gamma lines used in the measurements. In brackets, daughter nuclides that were used to determine parent nuclide activity.

\begin{tabular}{|c|c|}
\hline Isotope & Gamma lines [keV] \\
\hline${ }^{40} \mathrm{~K}$ & 1460.82 \\
\hline & 241.99 \\
\hline${ }^{226} \mathbf{R a}\left({ }^{\mathbf{2} 14} \mathrm{~Pb}\right)$ & 295.22 \\
& 351.93 \\
\hline${ }^{228} \mathrm{Ra}\left({ }^{\mathbf{2 1 2}} \mathrm{Pb}\right)$ & 238.63 \\
\hline & 338.32 \\
\hline${ }^{228} \mathbf{T h}\left({ }^{\mathbf{2 2 8}} \mathbf{A C}\right)$ & 911.19 \\
\hline${ }^{238} \mathbf{U}\left({ }^{234} \mathbf{T h}\right)$ & 968.96 \\
\hline
\end{tabular}

Primordial isotope ${ }^{232}$ Th cannot be measured by gamma-ray spectroscopy; however, its decay product ${ }^{228} \mathrm{Th}$ can be used as a proxy describing behavior of its parent nuclide, since these isotopes are expected to behave similarly during chemical processing.

Measurement results were combined with AoG process data to establish radionuclide massflow models through the Bayer process. The plant mass-flow data for one-day period was used.

\section{Results}

Summary of the gamma-spectroscopic measurement is provided in Table 4, while in this section results are presented in the form of daily activity flow (units of $[\mathrm{Bq} / \mathrm{kg}]$ ), normalized over mass of aluminium hydroxide on dry calcined basis, as in equation 1 . Complete radiological mass-balance for every specific nuclide is presented in Figures 2 - 6.

$$
\text { Normalized Activity }=\frac{\text { Sample activity } \times \text { Daily mass flow }}{\text { Aluminium hydroxide mass flow }}
$$


Additionally, enrichment ratio for every radionuclide was calculated according to equation 2 and compared to enrichment ratio of $\mathrm{Fe}_{2} \mathrm{O}_{3}$, which can be considered as largely inert oxide in the Bayer process (Vind et al., 2018a). Previous study for the AOG alumina plant has shown that mean enrichment ratio for iron oxide during one year period is 2.31 [ibid.].

$$
\text { Enrichment Ratio }=\frac{\text { Bauxite residue activity }}{\frac{\sum(\text { Bauxite activity } \times \text { Bauxite mass flow })}{\text { Total Bauxite mass flow }}}
$$

\subsection{Bayer process mass-flow}

Bayer process mass balance is presented after decalcitation for every analyzed isotope in figures 2-6. Solid material flow is denoted with black arrows while liquid with orange. Dashed arrow stands for slurries (solids suspended in process liquor). Values for liquid karst and lateritic slurries are not available as these materials were not available for measurements. For the remaining materials, results are presented in the form of normalized activity (see equation 1) to represent daily radionuclide mass flow through the plant. When radionuclide activity concentration remained below detector resolution, Minimal Detectable Amount (MDA) values were substituted to equations 1 and 2 .

\section{Ra228}

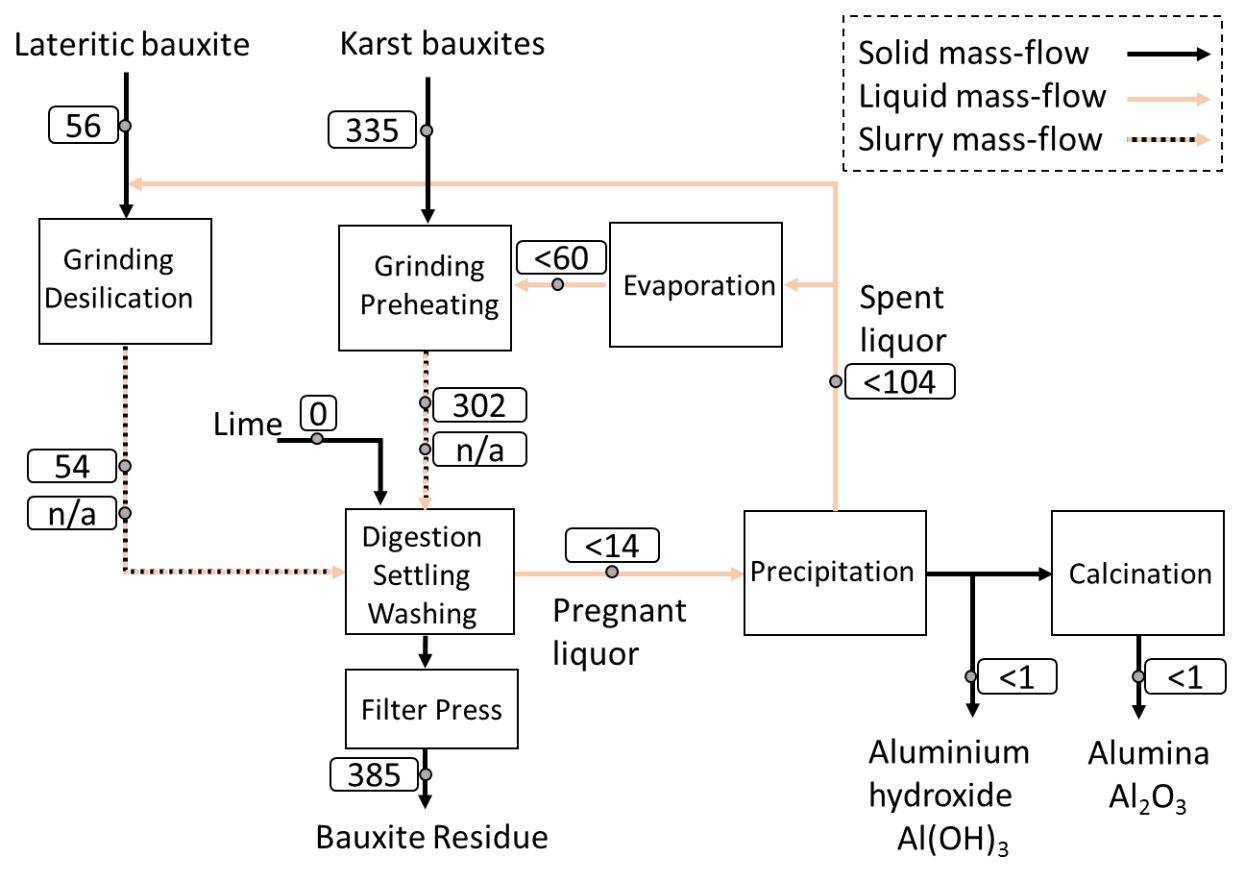

Figure 2. ${ }^{228} \mathrm{Ra}$ (product from thorium decay series) mass-flow through Bayer process. 


\section{Th228}

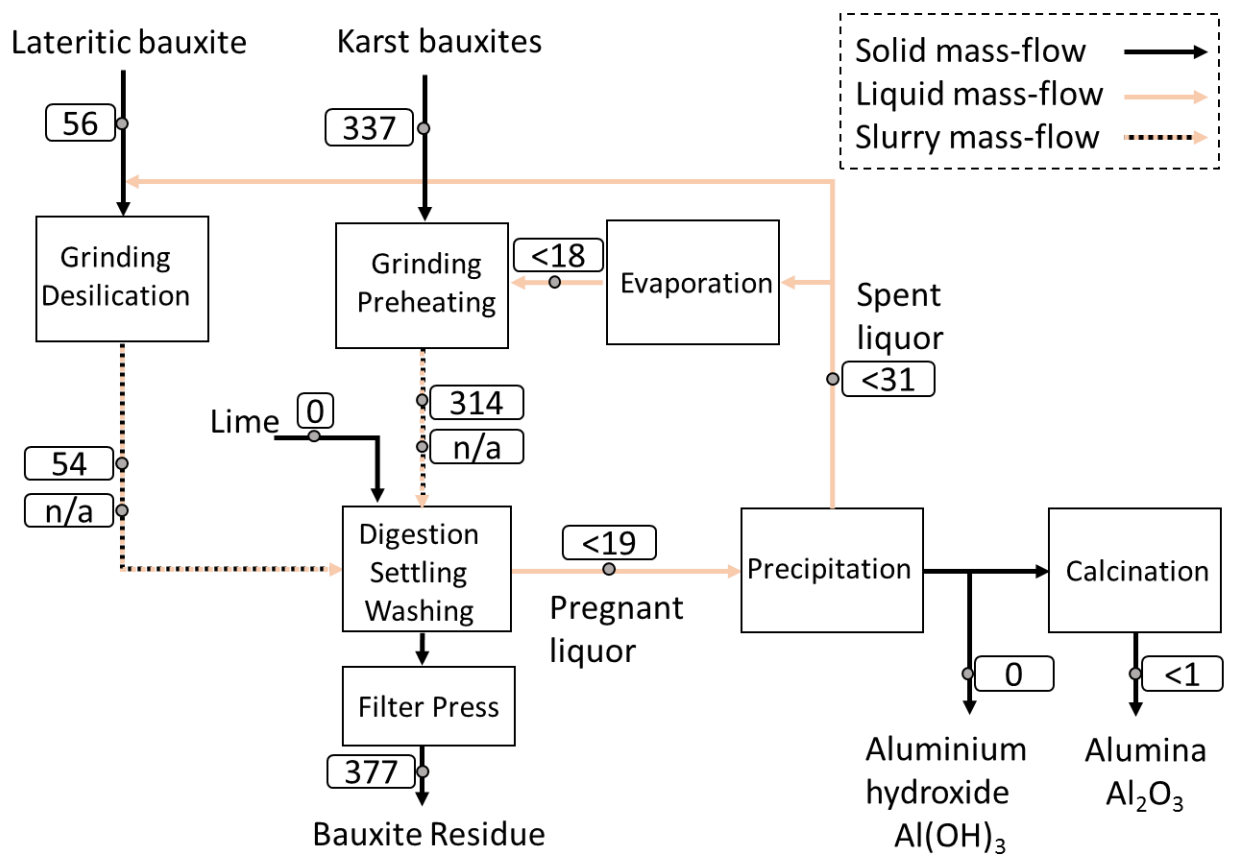

Figure 3. ${ }^{238}$ Th (product from thorium decay series) mass-flow through Bayer process.

${ }^{232} \mathrm{Th}$ was the most abundant radionuclide in the bauxites and bauxite residue presented in the current study. Its activity concentration was almost 3 times higher than ${ }^{238} \mathrm{U}$, while thorium element is 9 times more abundant than uranium in the bauxite residue studied in the current paper (conversion factors for primordial radionuclides are provided in Table 5). At the same time thorium is more hazardous from a radiological point of view (Joyce et al., 2017).

Figures 2 and 3 present ${ }^{228} \mathrm{Ra}$ and ${ }^{228} \mathrm{Th}$, decay products of ${ }^{232} \mathrm{Th}$. The behavior of the two nuclides was identical - both isotopes mostly end up in bauxite residue, while for liquors, hydrated and calcined alumina values remained below minimum detectable amounts. For ${ }^{228} \mathrm{Th}$ measured MDA was $0.5 \mathrm{~Bq} / \mathrm{kg}(0.12 \mathrm{mg} / \mathrm{kg})$ and $0.8 \mathrm{~Bq} / \mathrm{kg}(0.20 \mathrm{mg} / \mathrm{kg})$ for hydrated and calcined alumina respectively (see Table 4 and Table 5). There were no indications of dissolution of these isotopes in the process liquors.

For both lateritic and karst bauxite mixtures, thorium decay series isotope mass flow in the solid fraction of the sludge was slightly smaller than in the initial bauxites, meaning that portion of radionuclides goes to the liquid fraction of sludge. 


\section{U238}

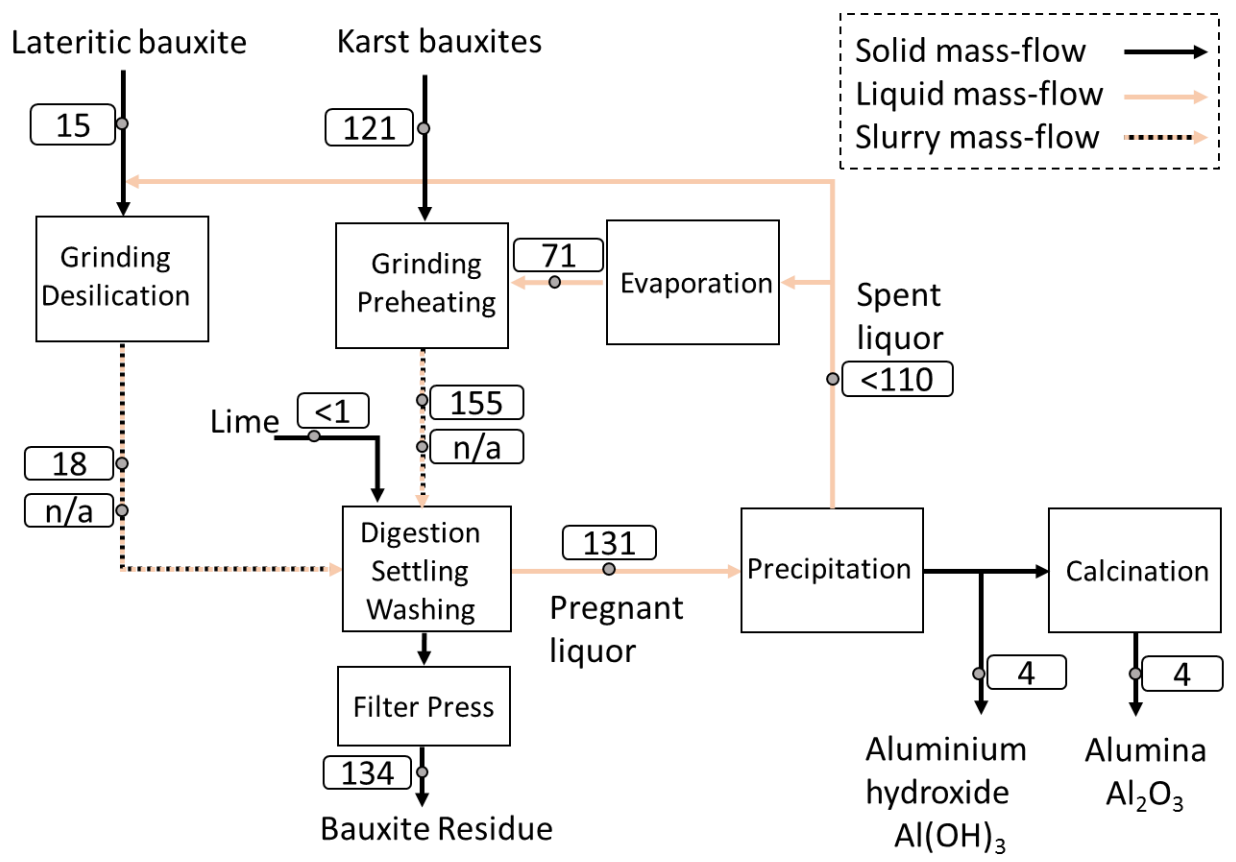

Figure 4. ${ }^{238} \mathrm{U}$ mass-flow through Bayer process.

Next, ${ }^{238} \mathrm{U}$, measured by its decay product ${ }^{234} \mathrm{Th}$, is presented in Figure 4. Initial activity concentration of uranium in bauxites was roughly one third of the same for thorium. It was observed that there was dissolution of uranium in the process liquors as well as there was increase of ${ }^{238} \mathrm{U}$ in the bauxite after they were mixed with liquors (lateritic and karstic slurries). However, most of the uranium still ended up in BR, while only minor portion, roughly $3 \%$ of initial amount went to aluminium. In the aluminium hydroxide $4 \mathrm{~Bq} / \mathrm{kg}{ }^{238} \mathrm{U}$ was measured, which is equivalent to $\sim 0.32 \mathrm{mg} / \mathrm{kg}$ uranium. It is in agreement with values published in the literature $0.5 \mathrm{mg} / \mathrm{kg}$ (Sato et al., 2013) and $0.3 \mathrm{mg} / \mathrm{kg}$ (Adams and Richardson, 1960) of uranium for aluminum hydroxide. After calcination, $5 \mathrm{~Bq} / \mathrm{kg}$ of ${ }^{238} \mathrm{U}$ was measured in calcined alumina, which corresponds to $\sim 0.4 \mathrm{mg} / \mathrm{kg}$. 


\section{Ra226}

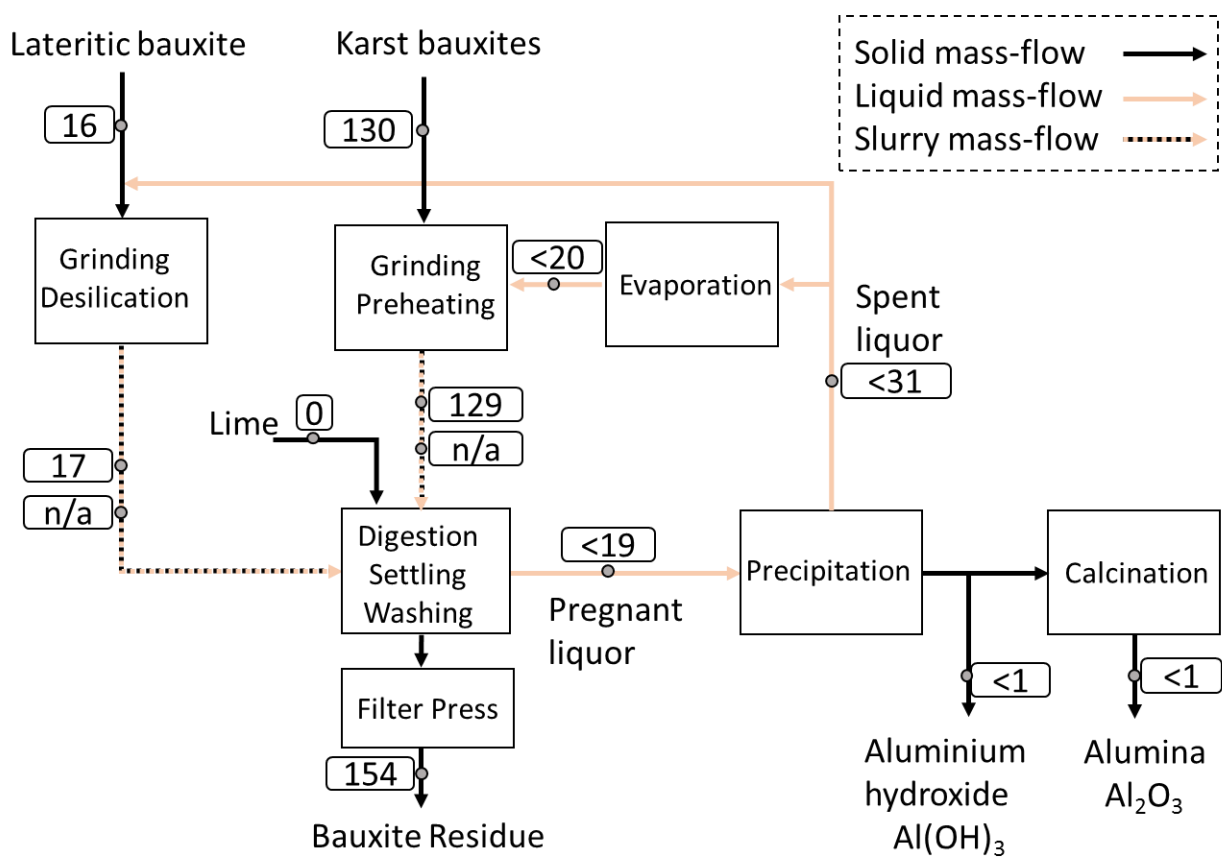

Figure 5. ${ }^{226} \mathrm{Ra}$ (product from uranium decay series) mass-flow through Bayer process.

${ }^{226} \mathrm{Ra}$ (decay product of ${ }^{238} \mathrm{U}$ ) is presented in Figure 5. It behaved similarly to decay products of thorium - it was not dissolved in the process liquors, it did not enter alumina either. The isotope flow also did not change significantly, when bauxites were mixed with liquor.

The MDA values for aluminium hydroxide and calcined alumina are 0.6 and $1.1 \mathrm{~Bq} / \mathrm{kg}$ respectively, which is a fraction of the measured ${ }^{238} \mathrm{U}$ activity concentration in these materials. Similarly, nothing was detected in process liquors, where MDA were 1.6, 2.4 and 2.7 for pregnant, spent and concentrated liquor respectively. 


\section{K40}

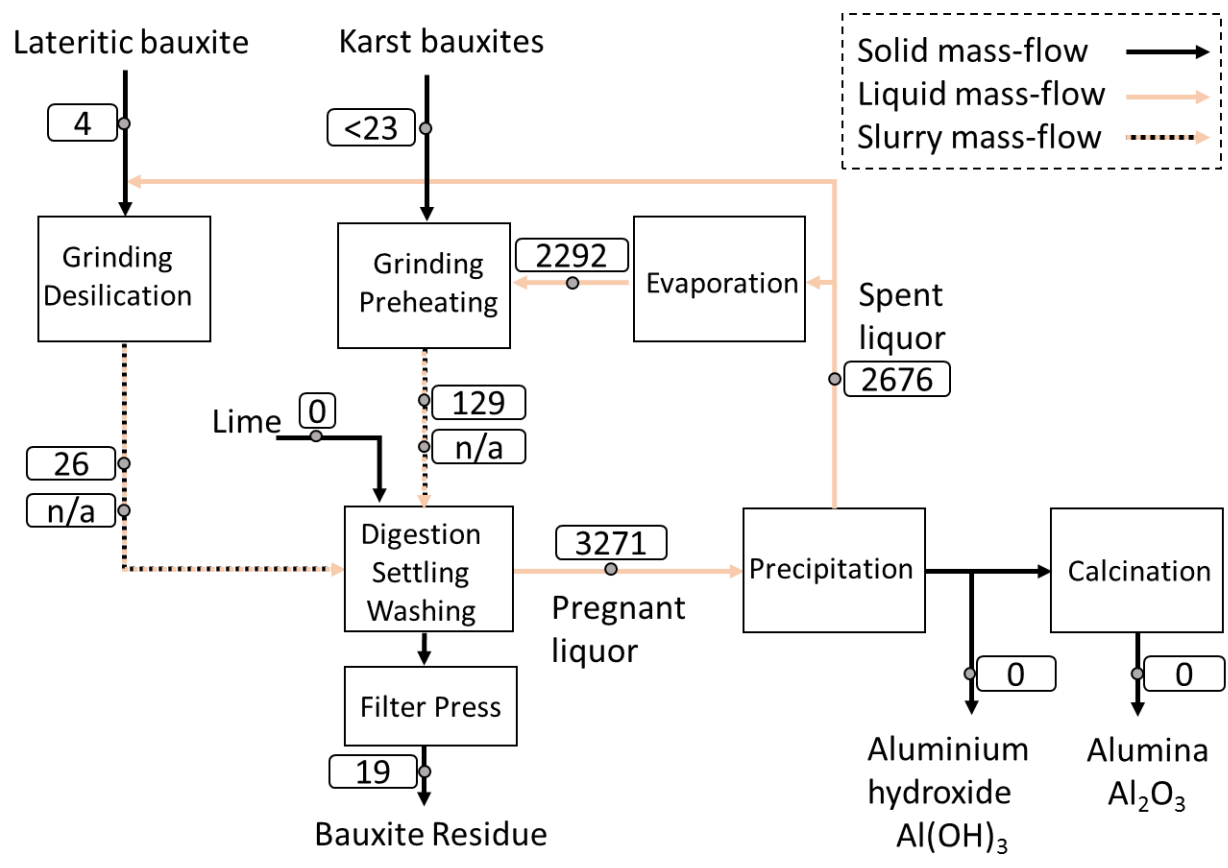

Figure $6 .{ }^{40} \mathrm{~K}$ mass-flow through Bayer process.

Finally, results for ${ }^{40} \mathrm{~K}$ are presented. Significant accumulation of ${ }^{40} \mathrm{~K}$ in the process liquors (high solubility of potassium in Bayer process liquor has been previously reported (Teas and Kotte, 1980), (Authier-Martin et al., 2001)) was observed, while nothing was found in the alumina. Isotope enrichment ratio to $\mathrm{BR}$ was only 1.7 , while for inert materials (based on $\mathrm{Fe}_{2} \mathrm{O}_{3}$ mass balance) enrichment ratio is 2.3; meaning portion of it is being potentially retained in the liquor. Scales produced at the plant have been analyzed (see Table 4); however, measurement uncertainties for scales were too high to properly judge presence of ${ }^{40} \mathrm{~K}$.

The discrepancy in the mass-flow of ${ }^{40} \mathrm{~K}$ could be explained by two factors: (1) there is significant variability in the output of this isotope in BR, as presented in Table 4; (2) there were significant uncertainties in the measurements of potassium. The content of radionuclide in bauxites and bauxite residue presented in the current study is 1-2 orders of magnitude lower than the isotope worldwide median concentration in soil (Unscear, 2008). For instance in Estonia, where measurements have been performed, mean ${ }^{40} \mathrm{~K}$ concentration in soil is $510 \mathrm{~Bq} / \mathrm{kg}$ [ibid.]. 


\subsection{Filter press stage.}

\begin{tabular}{|c|c|c|c|c|c|}
\hline Isotope & $\begin{array}{l}\text { Activity } \\
\text { [Bq/kg] }\end{array}$ & & Isotope & $\begin{array}{l}\text { Activity } \\
\text { [Bq/kg] }\end{array}$ & $\begin{array}{c}\text { Ratio } \\
\text { [\%] }\end{array}$ \\
\hline Ra228 & $439 \pm 11$ & & $\mathrm{Ra} 228$ & $435 \pm 11$ & 99 \\
\hline Th228 & $431 \pm 21$ & & Th228 & $425 \pm 21$ & 99 \\
\hline U238 & $158 \pm 8$ & & U238 & $151 \pm 9$ & 95 \\
\hline Ra226 & $180 \pm 2$ & & Ra226 & $174 \pm 2$ & 97 \\
\hline K40 & $23 \pm 5$ & & K40 & $22 \pm 6$ & 95 \\
\hline \multicolumn{2}{|c|}{ Bauxite Residue slurry } & Filter Press & Baus & Residue & \\
\hline
\end{tabular}

Figure 7. Activity concentration change during filter press stage.

Filter press has been installed at the AoG plant to reduce moisture content of the produced bauxite residue. During this stage, activity concentration of the residue material is reduced by one percent for thorium series, $3-5 \%$ for uranium series nuclides and ${ }^{40} \mathrm{~K}$. Recovered water is then reused in the process and does not leave the plant.

\section{Discussion}

\subsection{Mass balance}

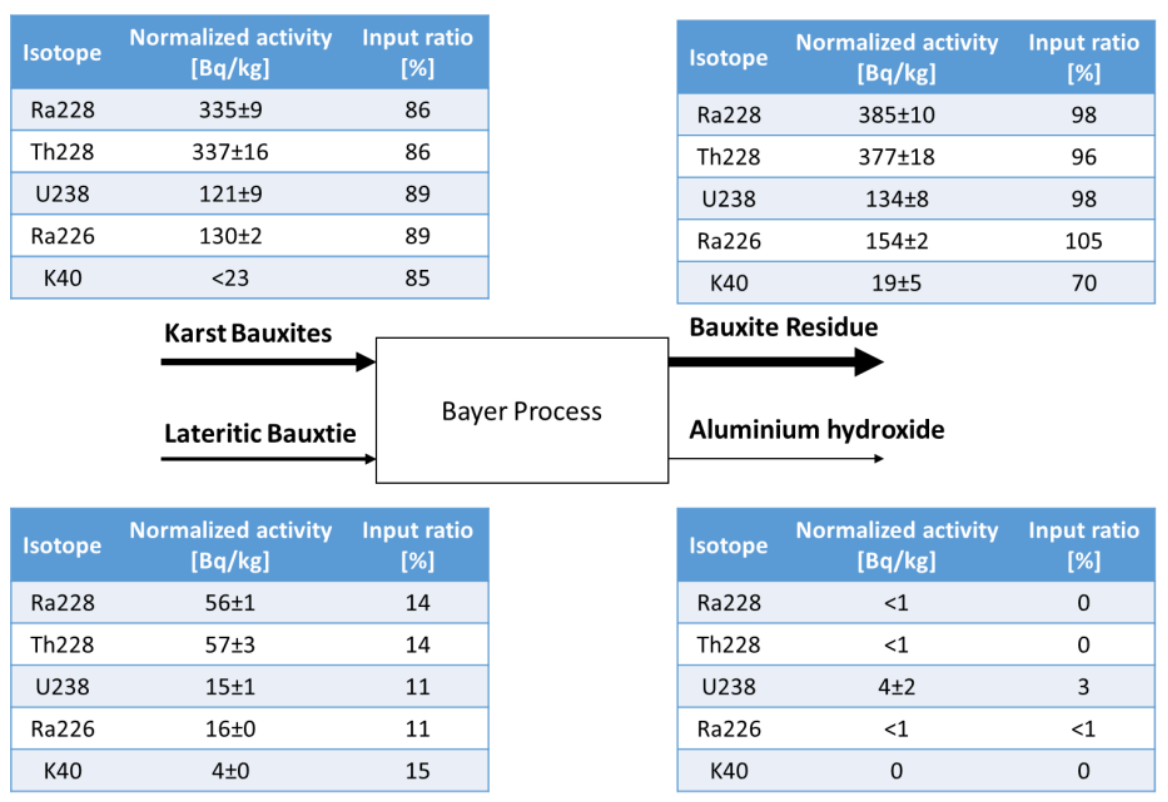

Figure 8. Summary of the radionuclide mass-balance.

Summary of the input and output radionuclide flow is provided in Figure 8 . The relative output 
ratio does not sum up exactly to $100 \%$, due to potential measurement and mass-balance uncertainties, while still provides quantitative representation. Currently discussed AOG plant uses two bauxite types- $79 \%$ of bauxite feed is karst and $21 \%$ is lateritic, while major proportion of radionuclides derives from karst bauxites. In the currently investigated mass balance karst bauxites provided $86 \%$ of thorium series, $89 \%$ of uranium series nuclides and $82 \%$ of ${ }^{40} \mathrm{~K}$, see Figure 8 . Most of these radionuclides ended up in the bauxite residue, while minor portion of ${ }^{238} \mathrm{U}$ isotope was found in alumina hydroxide, corresponding to $0.3 \mathrm{mg} / \mathrm{kg}$ and $0.4 \mathrm{mg} / \mathrm{kg}$ in calcined alumina. Thorium has previously been reported to enter alumina up to $4.9 \mathrm{mg} / \mathrm{kg}$ (Adams and Richardson, 1960), while in our study it remained below MDA values. The MDA values correspond to chemical content below $0.12 \mathrm{mg} / \mathrm{kg}$ and $0.22 \mathrm{mg} / \mathrm{kg}$ for hydrated and calcined alumina respectively (this assessment is based on the assumption that isotopes ${ }^{232} \mathrm{Th}$ and ${ }^{228} \mathrm{Th}$ behave in exactly the same way in the presented process).

Table 3: Radionuclide enrichment ratios.

\begin{tabular}{|c|c|}
\hline $\begin{array}{c}\text { Inert material (Vind et } \\
\text { al., } 2018 \mathrm{a})\end{array}$ & Enrichment ratio \\
\hline $\mathrm{Fe}_{2} \mathrm{O}_{3}$ & 2.31 \\
\hline Isotope & Enrichment ratio \\
\hline${ }^{238} \mathbf{U}$ & 2.30 \\
\hline${ }^{226} \mathbf{R a}$ & 2.45 \\
\hline${ }^{228} \mathbf{R a}$ & 2.29 \\
\hline${ }^{228} \mathrm{Th}$ & 2.24 \\
\hline${ }^{40} \mathrm{~K}$ & $>1.66$ \\
\hline
\end{tabular}

Isotope enrichment ratios in the bauxite residue (see equation 2 ) are summarized in Table 3. ${ }^{238} \mathrm{U},{ }^{226} \mathrm{Ra}$ and ${ }^{228} \mathrm{Th}$ are close to the enrichment ratio of $\mathrm{Fe}_{2} \mathrm{O}_{3}$, which is considered a largely inert material almost completely ending up in the BR. ${ }^{228} \mathrm{Ra}$, decay product of ${ }^{238} \mathrm{U}$, shows slight overestimation of the isotope in BR compared to feed bauxites (similarly to Figure 8). ${ }^{40} \mathrm{~K}$ has lowest enrichment ratio of 1.66 and the difference between input and output materials is $29 \%$. It was observed that significant amount of this radionuclide is accumulated in the process liquors and can be potentially explained by high variability of this isotope in bauxite residues (Table 4), where additional measurements of BR taken at a different date are provided. For instance, if ${ }^{40} \mathrm{~K}$ concentration from a sample Bauxite Residue 2 was substituted into mass balance, then enrichment ration would equal 2.27 and difference between output and input would be only $3 \%$. 


\subsection{Radiological indications}

Aluminium industry is not included in the EU Basic Safety Standard as one of the sectors involving naturally occurring radioactive materials. The reason for this is that radionuclide concentrations in input and output materials (bauxites and BR) are below exemption from regulatory control criteria set as $1000 \mathrm{~Bq} / \mathrm{kg}$ for ${ }^{238} \mathrm{U}$ and ${ }^{232} \mathrm{Th}$ (and their decay products), $10000 \mathrm{~Bq} / \mathrm{kg}$ for ${ }^{40} \mathrm{~K}$ (Council of the European Union, 2013). Measurement results for every studied material are summarized in Table 4. In case some isotope was not measured, MDA values are provided. It can be observed that every specific radionuclide in every studied material remains well below exemption levels set in EU BSS, considering uncertainties at $2 \sigma$ confidence level.

Current study confirms that there is no significant radionuclide accumulation during the Bayer process at the selected plant that could potentially cause elevated radiological exposure to workers or public.

Table 4. Activity concentrations of every sample measured during current study is summarized in the following table. Numbers in italic correspond to the radionuclide values below MDA. Errors are reported at $2 \sigma$ confidence level.

\begin{tabular}{|c|c|c|c|c|c|c|}
\hline \multirow{2}{*}{ Description } & \multicolumn{5}{|c|}{ Activity concentration $[\mathrm{Bq} / \mathrm{kg} \mathrm{d} . \mathrm{w} .]^{1}$} & \multirow[b]{2}{*}{${ }^{40} \mathrm{~K}$} \\
\hline & Number & ${ }^{228} \mathrm{Ra}$ & ${ }^{228} \mathrm{Th}$ & ${ }^{238} \mathrm{U}$ & ${ }^{226} \mathrm{Ra}$ & \\
\hline Trombetas bauxite & 1 & $129.2 \pm 3.6$ & $128.6 \pm 6.2$ & $35.5 \pm 3.2$ & $36.7 \pm 0.7$ & $<9.4$ \\
\hline Ghana bauxite & 2 & $112.0 \pm 3.2$ & $112.2 \pm 5.4$ & $34.4 \pm 3.2$ & $36.1 \pm 0.7$ & $<8.6$ \\
\hline Turkish bauxite & 3 & $180.7 \pm 5.0$ & $180.6 \pm 8.8$ & $98.7 \pm 6.6$ & $108.0 \pm 1.6$ & $103.2 \pm 6.4$ \\
\hline High-Silica bauxite & 4 & $189.1 \pm 5.2$ & $182.2 \pm 9.0$ & $96.7 \pm 6.4$ & $94.8 \pm 1.6$ & $5.0 \pm 4.2$ \\
\hline S\&B bauxite & 5 & $187.8 \pm 5.2$ & $184.0 \pm 9.0$ & $85.1 \pm 6.4$ & $87.3 \pm 1.5$ & $8.1 \pm 4.1$ \\
\hline Delphi-Distomon bauxite & 6 & $227.7 \pm 5.9$ & $222.7 \pm 10.8$ & $59.6 \pm 4.2$ & $69.9 \pm 1.1$ & $9.6 \pm 4$ \\
\hline Lime & 7 & $<2.2$ & $0.68 \pm 0.3$ & $<6.6$ & $2.4 \pm 0.3$ & $<11.4$ \\
\hline Decalcitated bauxite & 8 & $207.1 \pm 5.6$ & $208.7 \pm 10.2$ & $72.2 \pm 5.8$ & $77.7 \pm 1.3$ & $8.4 \pm 4.4$ \\
\hline Decalcitation residue & 9 & $97.6 \pm 3.0$ & $97.7 \pm 4.8$ & $62.9 \pm 53$ & $58.0 \pm 1.2$ & $13.7 \pm 5.0$ \\
\hline Lateritic bauxite slurry & 10 & $148.7 \pm 4.0$ & $148.5 \pm 7.2$ & $48.5 \pm 3.6$ & $45.6 \pm 0.9$ & $70.9 \pm 5.6$ \\
\hline Karstic bauxite slurry & 11 & $161.1 \pm 7.3$ & $167.2 \pm 8.8$ & $82.8 \pm 11.8$ & $68.7 \pm 2.6$ & $68.9 \pm 46.6$ \\
\hline $\begin{array}{c}\text { BR slurry before filter } \\
\text { press }\end{array}$ & 15 & $439.0 \pm 11.2$ & $430.6 \pm 20.8$ & $158.3 \pm 7.8$ & $180.3 \pm 2.2$ & $22.6 \pm 4.6$ \\
\hline Hydrated alumina & 16 & $<1.3$ & $<0.5$ & $3.9 \pm 2.0$ & $<0.6$ & $<6.7$ \\
\hline Calcined alumina & 17 & $<2.4$ & $<0.8$ & $4.9 \pm 2.8$ & $<1.1$ & $<13.0$ \\
\hline Bauxite Residue & 18 & $434.5 \pm 11.4$ & $425.0 \pm 20.6$ & $151.0 \pm 9.4$ & $173.6 \pm 2.4$ & $21.9 \pm 6.1$ \\
\hline Bauxite Residue $2^{2}$ & 18 & $419.9 \pm 5.5$ & $382.2 \pm 11.5$ & $\mathrm{n} / \mathrm{a}$ & $164.7 \pm 2.3$ & $29.9 \pm 9.1$ \\
\hline
\end{tabular}

\footnotetext{
${ }^{1}$ d.w.- dry weight

${ }^{2}$ Samples Bauxite Residue 2 and 3 have been obtained during different period and were not used in the current mass balance modelling. However, they represent radionuclide variability in this material. For these samples results for ${ }^{238} \mathrm{U}$ are not available, as equilibrium time (6 month) was not retained.
} 


\begin{tabular}{|c|c|c|c|c|c|c|}
\hline Bauxite Residue 3 & 18 & $439.9 \pm 5.5$ & $403.8 \pm 12.1$ & $\mathrm{n} / \mathrm{a}$ & $170.4 \pm 2.3$ & $25.5 \pm 8.5$ \\
\hline Process liquors & \multicolumn{5}{|c|}{ Activity concentration [Bq/l] } & \\
\hline Pregnant liquor & 12 & $<5.9$ & $<1.7$ & $11.8 \pm 8.6$ & $<1.6$ & $293.2 \pm 24.5$ \\
\hline Spent liquor & 13 & $<7.7$ & $<2.3$ & $<7.9$ & $<2.4$ & $263.3 \pm 27.9$ \\
\hline Concentrated liquor & 14 & $<8.1$ & $<2.5$ & $9.5 \pm 6.4$ & $<2.7$ & $308.2 \pm 27.7$ \\
\hline Scales & \multicolumn{5}{|c|}{ Activity concentration [Bq/kg d.w.] } & \\
\hline $\begin{array}{c}\text { Red scales from } \\
\text { evaporation }\end{array}$ & 19 & $<135$ & $<42.6$ & $<213$ & $<46.3$ & $<798$ \\
\hline $\begin{array}{c}\text { White scales from } \\
\text { evaporation }\end{array}$ & 20 & $<35.2$ & $<11.2$ & $<56.4$ & $<12.1$ & $<219$ \\
\hline Scales from digester & 21 & $82.7 \pm 12.4$ & $86.6 \pm 7.8$ & $<82.9$ & $26.4 \pm 5.4$ & $<292$ \\
\hline Scales from precipitators & 22 & $<3.0$ & $1.1 \pm 0.4$ & $<6.0$ & $<2.0$ & $<12.8$ \\
\hline
\end{tabular}

Table 5: Conversion factors from primordial radionuclides to chemical concentration.

\begin{tabular}{|c|c|}
\hline Isotope & Conversion \\
\hline${ }^{238} \mathrm{U}$ & $1 \mathrm{~Bq} / \mathrm{kg}=81 \mathrm{ng} / \mathrm{kg}$ \\
\hline${ }^{232} \mathrm{Th}$ & $1 \mathrm{~Bq} / \mathrm{kg}=246 \mathrm{ng} / \mathrm{kg}$ \\
\hline${ }^{40} \mathrm{~K}$ & $1 \mathrm{~Bq} / \mathrm{kg}=32.3 \mathrm{mg} / \mathrm{kg}$ \\
\hline
\end{tabular}

\subsubsection{Scales formed during Bayer process}

Additional measurements have been performed to analyze scales formed at different stages of the process. Measurement results are presented in Table 4. There is no significant radionuclide accumulation and all the scales produced stay below limits set by EURATOM BSS.

Isotope ${ }^{40} \mathrm{~K}$ was not detected in the scales. The MDA values for this isotope remained below EURATOM BSS limit, while remained high enough to prove or refute accumulation of potassium.

\section{Summary}

Current research focused on the radiological aspects of the Bayer process at the AoG plant, considering full spectrum of materials used. It was confirmed that at any stages of the plant operation radionuclide concentrations remained well below exemption levels set by EURATOM BSS, and there is no risk of elevated radiological exposure to personnel of the plant or to the public in the vicinity. However, it should be mentioned that current conclusion should not be extrapolated to other plants as the radionuclide content in bauxites as well as produced BRs differ significantly worldwide, likewise radiation protection legislation can vary in other countries. 
By studying results of the gamma-ray spectroscopy, it was observed, that specific karst bauxites (from Greece and Turkey) have significantly higher natural radionuclide concentrations compared to specific lateritic bauxites (from Ghana and Brazil). The difference was in the range of $1.7-2.4$ times for ${ }^{238} \mathrm{U}$ and $1.4-2.0$ times for ${ }^{232} \mathrm{Th}$. Potassium was presented in trace amounts in the analyzed bauxites $\left(<10 \mathrm{~Bq} / \mathrm{kg}\right.$ of ${ }^{40} \mathrm{~K}$ or $<0.32 \mathrm{~g} / \mathrm{kg}$ of potassium element), except for one specific bauxite type originating from Turkey, where 103.2 Bq/ kg of ${ }^{40} \mathrm{~K}$ was measured, corresponding to $3.3 \mathrm{~g} / \mathrm{kg}$ of potassium element.

Most of the radionuclides entering the process ended up in the bauxite residue with the minor exception of ${ }^{238} \mathrm{U}$, dissolution of which was observed in the process liquors and $3 \%$ of which entered alumina. Its long-lived decay product ${ }^{226} \mathrm{Ra}$ accumulated entirely in bauxite residue, meaning that the decay equilibrium is disturbed for this decay chain. ${ }^{40} \mathrm{~K}$ was also observed to dissolve and accumulate in the process liquors; however, it was not detected in hydrated or calcined alumina.

\section{Acknowledgements}

The research leading to these results has received funding from the European Community's Horizon 2020 Programme ([H2020/2014-2019]) under Grant Agreement no. 636876 (MSCAETN REDMUD). This publication reflects only the authors' view, exempting the Community from any liability. Project website: http://www.etn.redmud.org.

\section{References}

Adams, J.A.S., Richardson, K.A., 1960. Radioactivity of Aluminum Metal. Econ. Geol. 55, 10601063.

Armstrong, J.A., 1999. The investigation of scale formation in the Bayer process. Loughborough University.

Authier-Martin, M., Forte, G., Ostap, S., See, J., 2001. The mineralogy of bauxite for producing smelter-grade alumina. JOM 53, 36-40. doi:10.1007/s11837-001-0011-1

Balomenos, E., Gianopoulou, I., Panias, D., Paspaliaris, I., 2009. ENEXAL: Novel technologies for enhanced energy and exergy efficiencies in primary aluminium production industry. Metal. - J. Metall. 15, 203-217.

Bardossy, G., 1982. Karst Bauxites- Bauxite Deposits on Carbonate Rocks, Vol. 14. ed. Elsevier, Amsterdam.

Bardossy, G., Aleva, G.J.J., 1990. Lateritic Bauxites. Elsevier, Amsterdam, New York.

Beddow, H., Black, S., Read, D., 2006. Naturally occurring radioactive material (NORM) from a former phosphoric acid processing plant. J. Environ. Radioact. 86, 289-312. doi:10.1016/j.jenvrad.2005.09.006

Bou-Rabee, F., Al-Zamel, A.Z., Al-Fares, R.A., Bem, H., 2009. Technologically enhanced naturally occurring radioactive materials in the oil industry (TENORM). A review. Nukleonika 54, 3-9.

Chin, L.A.D., 1988. The state-of-the-art in Bayer process technology. Light Met. 1988 49-53. 
doi:10.1007/BF03258904

Council of the European Union, 2013. Council Directive 2013/59/Euratom. Off. J. Eur. Union 56, 216. doi:doi:10.3000/19770677.L_2013.124.eng

Cuccia, V., Oliveira, A.H. De, Rocha, Z., 2011. Radionuclides in Bayer Process Residues: Previous Analysis for Radiological Protection. Int. Nucl. Atl. Conf. - Ina. 2011.

Deady, É.A., Mouchos, E., Goodenough, K., Williamson, B.J., Wall, F., 2016. A review of the potential for rare-earth element resources from European red muds: examples from Seydişehir, Turkey and Parnassus-Giona, Greece. Mineral. Mag. 80, 43-61. doi:10.1180/minmag.2016.080.052

Gamaletsos, P., Godelitsas, A., Mertzimekis, T.J., Göttlicher, J., Steininger, R., Xanthos, S., Berndt, J., Klemme, S., Kuzmin, A., Bárdossy, G., 2011. Thorium partitioning in Greek industrial bauxite investigated by synchrotron radiation and laser-ablation techniques. Nucl. Instruments Methods Phys. Res. Sect. B Beam Interact. with Mater. Atoms 269, 3067-3073. doi:10.1016/j.nimb.2011.04.061

Gamaletsos, P.N., Godelitsas, A., Kasama, T., Kuzmin, A., Lagos, M., Mertzimekis, T.J., Göttlicher, J., Steininger, R., Xanthos, S., Pontikes, Y., Angelopoulos, G.N., Zarkadas, C., Komelkov, A., Tzamos, E., Filippidis, A., 2016. The role of nano-perovskite in the negligible thorium release in seawater from Greek bauxite residue (red mud). Sci. Rep. 6, 21737. doi:10.1038/srep21737

Hind, A.R., Bhargava, S.K., Grocott, S.C., 1999. The surface chemistry of Bayer process solids: A review. Colloids Surfaces A Physicochem. Eng. Asp. 146, 359-374. doi:10.1016/S09277757(98)00798-5

IAEA, 2003. Extent of Environmental Contamination by Naturally Occurring Radioactive Material (NORM) and Technological Options for Mitigation, La Prensa medica mexicana. Vienna.

IAEA, 1987. Preparation and certification of IAEA gamma-ray spectrometry reference materials RGU-1, RGTh-1 and RGK-1. laea-RI-148 48.

Joyce, P.J., Goronovski, A., Tkaczyk, A.H., Björklund, A., 2017. A framework for including enhanced exposure to naturally occurring radioactive materials (NORM) in LCA. Int. J. Life Cycle Assess. 22. doi:10.1007/s11367-016-1218-2

Lavalou, E., Bosca, B., Keramidas, O., 1999. Alumina production from diasporic bauxites. Light Met. 55-62.

Miller, M.O., Miller, D.A., 2016. The Technological Enhancement of Normally Occurring Radioactive Materials in Red Mud due to the Production of Alumina. Int. J. Spectrosc. 2016. doi:10.1155/2016/4589460

Mucsi, G., Csoke, B., Solymár, K., 2011. Grindability characteristics of lateritic and karst bauxites. Int. J. Miner. Process. 100, 96-103. doi:10.1016/j.minpro.2011.05.006

Paspaliaris, I., Panias, D., Skoufadis, C., 2001. Precipitation and Calcination of Monohydrate Alumina From the Bayer Process Liquors, in: EUROTHEN 2001, July 4-6. Stockholm.

Sato, C., Kazama, S., Sakamoto, A., Hirayanagi, K., 2013. Behavior of Radioactive Elements (Uranium and Thorium) in Bayer Process. Essent. Readings Light Met. Alumina Bauxite, Vol. 1 1, 191-197. doi:10.1002/9781118647868.ch25

Teas, E.B., Kotte, J.J., 1980. The Effect of Impurities on Process Efficiency and Methods of Impurity Control and Removal, in: Bauxite/Alumina Industry in the Americas.

Unscear, 2008. Sources and effects of ionizing radiation I, 472. 
Vidmar, T., 2005. EFFTRAN-A Monte Carlo efficiency transfer code for gamma-ray spectrometry. Nucl. Instruments Methods Phys. Res. Sect. A Accel. Spectrometers, Detect. Assoc. Equip. 550, 603-608. doi:10.1016/j.nima.2005.05.055

Vind, J., Alexandra, A., Vicky, V., Panias, D., 2018a. Distribution of Selected Trace Elements in the Bayer Process. Metals (Basel). 8. doi:10.3390/met8050327

Vind, J., Malfliet, A., Blanpain, B., Tsakiridis, P., Tkaczyk, A., Vassiliadou, V., Panias, D., 2018b. Rare Earth Element Phases in Bauxite Residue. Minerals 8, 77. doi:10.3390/min8020077

Vind, J., Malfliet, A., Bonomi, C., Paiste, P., Sajó, I.E., Blanpain, B., Tkaczyk, A.H., Vassiliadou, V., Panias, D., 2018c. Modes of occurrences of scandium in Greek bauxite and bauxite residue. Miner. Eng. 123, 35-48. doi:10.1016/J.MINENG.2018.04.025 